MISCELLANEA

\title{
The Origin of the Term 'Byssinosis' \\ BY
}

\author{
ALY MASSOUD \\ From the Nuffield Department of Occupational Health, \\ University of Manchester
}

(RECEIVED FOR PUBLICATION NOVEMBER 11, 1963)

The Departmental Committee on Compensation for Cardroom Workers adopted in 1939 the term 'byssinosis'. Since then it has appeared extensively in literature dealing with respiratory disease of textile workers. It connotes an affection of the chest, characterized by the 'Monday tightness' found in those exposed to the inhalation of the dust of cotton, flax, jute, or hemp.

The word byssinosis is derived from the Greek $\beta$ viroos or Latin byssus. The exact meaning of this word byssus is at best uncertain. It is doubtful whether it originally belonged to the vegetable, animal, or mineral kingdom. Zoologists still use byssus-gland found in the foot of the Pinna marina (a bivalve mollusc) by which it and various other mussels attach themselves to the surface of the rocks. Botanists still give the name byssus to the threadlike stripe of some fungi. For the geologist, byssus is an obsolete name for asbestos, although byssolite is still in use as a synonym for asbestoid (The Shorter Oxford Dictionary, 1962). The same source gives the commonest use of byssus as "An exceedingly fine and valuable textile fibre and fabric known to the ancients, it denoted properly a kind of flax, but used also of cotton, silk, etc. . . .'

Baines (1835) quoted Isidore (orig. xix. c. 27) as saying that byssus was an exceedingly white and soft kind of flax, and Jullus Pollax (lib. vii. 12), who said that it denoted the finest flax and cotton, while Pausanias stated (in Eliacis I, 1) that byssus grew in Egypt, Judea, India, and Elis (Greece), which was true of flax, but cotton certainly did not at that time grow in any part of Greece. John de Trevisa (1326-1412) wrote 'The Fayrest of al (Flaxe) growyth in Egypte, for thereof is bissus made ryght fayre and whyte as snowe'. Thus, wherever the word byssus is used it means a very fine white silky fibre.

The word 'byssinosis' has been attributed by many authors to Sir Thomas Oliver $(1902,1908)$, who did not quote its origin. The last author to discuss it was Meiklejohn (1963), who stated that the word byssinosis was invented by Oliver. This is not the case. Going back to 1871, Ludwig Hirt, in the first volume (Part 1) of his book on the diseases of workers, Die Krankheiten der Arbeiter, considered (chapter 4, section II) the inhalation of cotton dust, 'Die Einlagerung von Baumwollenstaub in die Lunge'. He discussed the clinical history and the pathology of cotton workers' lungs, quoting Van
Coetsem, but he disagreed with Coetsem in calling it 'pneumonie cotonneuse'. Because Hirt classified it as one of the dust diseases he preferred to call it 'pneumoconiosis lyssinotica' and, for short, 'lyssinosis pulmonum'. 'Sollte es sich dann wirklich herausstellen, dass Baumwolle in der Lunge ist, so würde diese Affection nicht mehr als pneumonie cotonneuse, sondern der Gleichmässigkeit wegen vielleicht als Pneumoconiosis lyssinotica ( $\left.\lambda v^{\prime} \sigma \sigma a\right)$ oder kurz als Lyssinosis pulmonum, Baumwollenlunge unter den übrigen Staubinhalationskrankheiten zu figuriren haben'.*

It is obvious, however, that he misused the word lýssa ( $\lambda \dot{v} \sigma \sigma \alpha)$ for byssus ( $\left.\beta v_{\sigma \sigma o s}\right)$. This is surprising from a German scientist because the word lyssa, which means rabies in Greek, also means rabies in German. AchilleAdrien Proust (1877) discovered Hirt's mistake: 'C'est à tort que Hirt écrit Lyssinosis. Par une singulière inadvertance l'auteur allemand confond $\lambda \dot{v} \sigma \sigma \alpha$, rage avec Búroos, coton.' Proust (1877) used the correct term 'byssinosis' in his article-'Affections pulmonaires succédant à l'inhalation des poussières de cotonbyssinosis'-and to him, therefore, must be attributed its origin.

I am grateful to Professor R. E. Lane for his encouragement and help, to Dr. A. Meiklejohn for sending me a copy of Proust's article, only present in the Royal College of Physicians, Edinburgh, and to my wife for help with the German and French translations.

\section{REFERENCES}

Baines, E. (1835). History of the Cotton Manufacture in Great Britain. Appendix, p. 533. Fisher, Fisher and Jackson, London.

Departmental Committee on Compensation for Cardroom Workers (1939). Report, Home Office. H.M.S.O., London. Hirt, L. (1871). Die Krankheiten der Arbeiter, Vol. 1, Part 1, p. 57.

Meiklejohn, A. (1963). Int. Arch. Gewerbepath. Gewerbehyg., 20, 49. Oliver, T. (1902). Dangerous Trades, p. 273. Murray, London. (1908). Diseases of Occupation, p. 247. Methuen, London.

Proust, A. A. (1877). Traité d'hygiène publique, 7, 171 .

Van Coetsem (1836). Annales de Médecine Belge et Etrangère, Vol. 3, p. 3, Brüssel.

*(If it is proved that there is cotton in the lungs, this disease would not be called 'cotton pneumonia', but, to be more representative, it may be called 'lyssinotic pneumoconiosis' or in short 'pulmonary lyssinosis'; the disease of the lungs due to cotton should be tabled lyssinosis'; the disease
under dust diseases.) 